\title{
Molecular phylogeny and chromosomal evolution of endemic species of Sri Lankan Anacardiaceae
}

\author{
M Ariyarathne ${ }^{1,2}$, D Yakandawala ${ }^{1,2^{*}}$, M Barfuss $^{3}$, J Heckenhauer ${ }^{4,5}$ and R Samuel ${ }^{3}$ \\ ${ }^{1}$ Department of Botany, Faculty of Science, University of Peradeniya, Peradeniya. \\ ${ }^{2}$ Postgraduate Institute of Science, University of Peradeniya, Peradeniya. \\ ${ }^{3}$ Department of Botany and Biodiversity Research, University of Vienna, Austria. \\ ${ }^{4}$ LOEWE Centre for Translational Biodiversity Genomics (LOEWE-TBG), Frankfurt, Germany. \\ ${ }^{5}$ Department of Terrestrial Zoology, Entomology III, Senckenberg Research Institute and Natural History Museum Frankfurt, Frankfurt, Germany.
}

Received: 14 August 2019; Revised: 29 January 2020; Accepted: 29 May 2020

\begin{abstract}
Family Anacardiaceae comprises 70 genera and approximately 985 species distributed worldwide. Sri Lanka harbours 19 species in seven genera, among these 15 are endemics. This study focuses on regionally restricted endemics and native Anacardiaceae species, which have not been investigated before at molecular and cytological level. Nuclear rDNA ITS and plastid matK regions were sequenced for ten species, having nine endemics and one native, and incorporated into the existing sequence data for phylogenetic analyses. The topologies resulting from maximum parsimony, maximum likelihood and Bayesian inference are congruent. Family Anacardiaceae forms a monophyletic group having monophyletic subfamily Anacardioideae and paraphyletic subfamily Spondioideae. Tribes Anacardieae, Semecarpeae and Rhoeae form subclades within the major clade of Anacardioideae. All the endemic species occupy correct position in the molecular phylogeny as per the existing classification except for Campnosperma zeylanica, which shows a close relationship to members of the subfamily Spondioideae. The position of non-native species Trichoscypha acuminata also remains unclear. Chromosome counts and karyograms were constructed for five endemic species. The chromosome numbers incorporated in the tree range from $2 n=28-58$. Species of tribe Rhoeae have the lowest chromosome number $(2 n=24,28,30)$ while species of tribe Semecarpeae have the higher numbers ( $2 n$ $=50,52,58)$. Chromosome numbers mapped on the phylogeny shows that dysploidy had played a role in the evolution of the species of the family Anacardiaceae in Sri Lanka.
\end{abstract}

Keywords: Anacardiaceae, Campnosperma zeylanica, chromosome counts, molecular phylogeny, Semecarpus species.

\section{INTRODUCTION}

Family Anacardiaceae R. Br., the cashew family, contains 70 genera harbouring 985 species of trees, shrubs and subshrubs. The members are well known for causing contact dermatitis reactions. They occupy a considerable fraction of the tropical flora dispersed in tropical, subtropical and temperate regions holding Malaysian region as the center of diversity ( $\mathrm{Li}, 2007$; Pell et al., 2010; Zotz, 2013). As a tropical country, Sri Lanka nourishes 19 wild species including 15 endemics and numerous cultivated and hybrid species (MOE, 2012).

Some members of the family are cultivated throughout the world for their edible fruits and seeds such as cashew (Anacardium occidentale L.), mango (Mangifera indica $\mathrm{L}$. and numerous varieties), and hog plums (Spondias L.). In addition, some species have great medicinal properties: to treat fever (Buchanania Spreng., Comocladia P.Br.), for hepatitis (Haematostaphis Hook. f.), and for gastrointestinal illness (Anacardium L., Antrocaryon Pierre). Some species are known for quality wood and rot resistant timber such as quebracho (Schinopsis Engl.), as well as for landscaping (Cotinus Mill. and Toxicodendron Mill.) (Pell et al., 2010).

Earlier investigations suggest that the origin of this family is 55 to 65 MYA in the Paleocene era (Hsu, 1983;

\footnotetext{
"Corresponding author (deepthiy@pdn.ac.lk; (10) https://orcid.org/0000-0003-2441-5510)
} 
Muller, 1984). According to Gentry (1982) Anacardiaceae has a Gondwanan origin which is supported by fossil records as well as the current worldwide distribution of the family.

Anacardiaceae belongs to phylum Tracheophyta, class Magnoliopsida, order Sapindales. The family was first proposed by Lindley in 1830. Different classification systems were proposed for the family through the years (Table 1). From newly emerging research findings in recent years, Kim et al., (2017) were able to sequence the complete chloroplast genome of Rhus chinensis Mill, and Jo et al. (2017) were able to sequence the complete plastome of Mangifera indica. These findings will aid to increase the robustness of the phylogenetic interpretation of the family Anacardiaceae in the future. However, despite a number of taxonomic treatments, phylogenetic positions of many understudied genera are yet to be revealed.

Chromosome numbers have been used for taxonomical treatments (Cox et al., 1998; Bateman et al., 2003; Schneeweis et al., 2004; Almeida et al., 2007; Koch et al., 2012). According to Vinicius da Luz et al., (2015), only $14 \%$ species belonging to the family Anacardiaceae have been investigated cytologically. Raven (1975) justified and concluded that the ancestral basal chromosome number of the family is $x=7$, suggesting that the evolution of the family is at tetraploid level. Of the two subfamilies of Anacardiaceae, subfamily Anacardioideae has been cytologically studied from early ages. Maheshwari (1934) initiated the chromosomal studies on the genus Mangifera giving an uncertain chromosome number for $M$. indica $L$. as $2 n=52-58$ and later, Darlington and Ammal (1955) stated the number as $2 n=40$. These studies were expanded by Mukherjee $(1950 ; 1957)$ and Pierozzi and Rossetto (2006) by investigating chromosome counts for different species of the genus Mangifera and varieties of $M$. indica, and confirmed the somatic number as $2 n=40$. Index to Plant Chromosome Numbers (IPCN) gives seven records of gametophytic count of Semecarpus anacardium L.f. as $n=29$ and $n=30$ (Mehra, 1976; Gill et al., 1981;1990; Bir et al., 1982; Singhal \& Gill, 1990). The Flora of Malesiana has stated that the chromosome count of Semecarpus L.f. as $2 n=60$ (Hou, 1978) while Pell et al. (2010) confirmed that the gametophytic count of genus Semecarpus is $n=30$. Chromosome number of the genus Pistacia varies as $2 n=24,28$ and 30 (Huang et al., 1989; Parfitt \& Badenes, 1997). Among the species of subfamily Spondiadeae, $2 n=32$ is the common diploid number found in Spondias spp. and Dracontomelon dao (Blanco) Merr. \& Rolfe (respectively in Almeida et al., 2007; Oginuma et al., 1999). Sclerocarya caffra Sond. exhibits a sporophytic count of $2 n=26$ (Paiva \& Leitao, 1989), Lannea coromandelica (Houtt.) Merr. and Poupartia axillaris (Roxb.) King \& Prain have gametophytic counts of $n=15$ (Singhal \& Gill, 1990) and $n=12$ (Mehra, 1976), respectively. Almeida et al. (2007) revealed the presence of large blocks of heterochromatin

Table 1: Summary of classification systems of Anacardiaceae established by different authors. Tribes (Tr.), groups (Gr.), clades (Cl.) and the subfamilial (Subfam.) classification are shown.

\begin{tabular}{|c|c|}
\hline Author & Interfamilial affinities (Tr./ Gr./ Cl./ Subfam.) \\
\hline Bentham and Hooker (1862) & Tr. Anacardieae and Tr. Spondieae \\
\hline Marchand (1869) & $\begin{array}{l}\text { Tr. Astronieae, Tr. Buchananieae, Tr. Mangifereae, Tr. Pistacieae, Tr. Rhoideae, Tr. Semecarpeae, Tr. Spondieae, } \\
\text { Tr. Tapirieae, Tr. Thyrsodieae }\end{array}$ \\
\hline Eichler (1875-1878) & Gr. Anacardium, Gr. Pistacia, Gr. Rhus, Gr. Schinus, and Gr. Spondias \\
\hline Engler $(1881,1883,1892)$ & Tr. Dobineeae, Tr. Mangifereae, Tr. Rhoideae, Tr. Semecarpeae, Tr. Spondieae \\
\hline Takhtajan (1987) & $\begin{array}{l}\text { Subfam. Anacardioideae, Subfam. Spondioideae (Spondieae, Rhoideae, Semecarpeae), Subfam. Julianoideae, } \\
\text { Subfam. Pistacioideae, Subfam. Dobineoideae }\end{array}$ \\
\hline Mitchell and Mori (1987) & Subfam. Anacardieae, Subfam. Spondiadeae, Subfam. Semecarpeae, Subfam. Rhoeae, Subfam. Dobineae \\
\hline Wannan and Quinn (1991) & $\begin{array}{l}\text { Gr. A: (Tr. Anacardieae, Dobineae, Rhoeae, and Semecarpeae excluding four genera), } \\
\text { Gr. B: (Tr. Spondiadeae with Androtium, Buchanania, Campnosperma, and Pentaspadon) }\end{array}$ \\
\hline Terraza (1994) & $\begin{array}{l}\text { Cl. A1 (Anacardieae, Dobineae, Rhoeae, and Semecarpeae), } \\
\text { Cl. A2 (Tr. Spondiadeae and genus Pentaspadon) }\end{array}$ \\
\hline Takhtajan (1997) & $\begin{array}{l}\text { Subfam. Anacardioideae, Subfam. Spondioideae (Spondiadeae, Rhoeae, Semecarpeae), Subfam. Julianioideae, } \\
\text { Subfam. Pistacioideae }\end{array}$ \\
\hline Pell (2004) & Subfam. Anacardioideae and Subfam. Spondioideae \\
\hline Mitchell et al., 2006 & Subfam. Anacardioideae and Subfam. Spondioideae (with emended descriptions and circumscriptions) \\
\hline
\end{tabular}


$\mathrm{CMA}^{+}$in the species of the genus Spondias. The number and location of CMA bands were found to vary among the Spondias species and the distribution patterns of these heterochromatin blocks can be used to identify each Spondias species separately (Almeida et al., 2007).

Chromosomal evolution of angiosperms has been widely discussed among the taxonomic community for decades (Cox et al., 1998; Schneeweiss et al., 2004; Hansen et al., 2006; Mayrose et al., 2009; Duan et al., 2015) while cytological evolution of many plant families still remains unknown. This study is an attempt to bridge this gap in chromosomal evolution in Angiosperms by contributing molecular and cytological data on regionally restricted species of the family Anacardiaceae. The present investigation mainly focused on endemic and native species of the family Anacardiaceae in Sri Lanka. Here we address (1) clarification of the phylogenetic position of the endemic and native taxa using nuclear ITS and plastid matK regions; (2) chromosomal counts for endemic species; and (3) analysis and investigation of the evolution of chromosome number across the combined phylogeny.

\section{METHODOLOGY}

\section{Materials for molecular phylogeny and chromosome counts}

Sampling included ten species of four genera representing all the genera with endemics in the country, which also corresponds to three tribes out of four found in Sri Lanka. Collected locations of each species are given in Ariyarathne et al. (2017). All the species investigated were included in separate and in combined phylogenetic analyses. Cytological studies were conducted only in five species due to unavailability of viable seeds to obtain actively growing young roots. Vegetative propagation using different media was attempted as an alternative but unfortunately none of the trails gave positive results due to high level of secondary metabolites in secretions. Semecarpus seeds were stored in air tight bags for 1-3 wk until germination initiated and later transferred to air tight units with moistened coir dust medium and then placed at $\pm 20{ }^{\circ} \mathrm{C}$ temperature, having $12 \mathrm{~h}$ light and $12 \mathrm{~h}$ dark cycles. Seeds of Mangifera zeylanica were potted in a sand medium and transferred to a soil medium after the germination. Actively growing rootlets, grown up to $1 \mathrm{~cm}$, were used for chromosome counts.

\section{DNA extraction and PCR amplification}

Genomic DNA was extracted from c. $45 \mathrm{mg}$ silica gel dried leaf materials (Chase \& Hills, 1991) using Qiagen DNeasy Plant Mini Kit (Qiagen, Hilden, Germany) following the manufacturer's protocol. As an initial step to remove mucilaginous polysaccharides, the ground samples were washed 2-10 times with sorbitol buffer until no visible mucilaginous substances appeared in the sample solution (Russell et al., 2010; Souza et al., 2012).

Two gene regions were amplified by polymerase chain reaction using six primers; nuclear genomic ITS1 and ITS-2 (rDNA ITS) regions, and plastid matK (partial trnK intron with complete matK gene) region (Table 2). PCR amplifications were carried out with 40 $\mu \mathrm{L}$ reaction mixture containing $20 \mu \mathrm{L}$ of $1 \mathrm{x} \mathrm{GoTaq}^{\circledR}$ Green Master Mix (Promega Corporation, USA), $1.6 \mu \mathrm{L}$ of $25 \mathrm{mM} \mathrm{MgCl}, 1.6 \mu \mathrm{L}$ of $10 \mathrm{mg} / \mathrm{mL}$ bovin serum albumin (BSA) acetylated, $0.8 \mu \mathrm{L}$ of $5 \mathrm{u} / \mu \mathrm{L}$

Table 2: Details of primers used in this study. Utility of each primer during this study is given as used for PCR amplifications (PCR) or/and DNA sequencing (Seq).

\begin{tabular}{|c|c|c|c|c|c|}
\hline \multirow[t]{2}{*}{ Region } & \multirow[t]{2}{*}{ Primer } & \multirow[t]{2}{*}{ Sequence $\left(5^{\prime}-3\right)$} & \multicolumn{2}{|c|}{ Utility } & \multirow[t]{2}{*}{ Reference } \\
\hline & & & PCR & Seq & \\
\hline \multirow[t]{2}{*}{ ITS } & ITS 4 & TCCTCCGCTTATTGATATGC & PCR & Seq & White et al., 1990 \\
\hline & ITS 5 & GGAAGTAAAAGTCGTAACAAGG & PCR & Seq & White et al., 1990 \\
\hline \multirow[t]{7}{*}{ matK } & $\operatorname{trnK}-799 f$ & CCYTGTTYTRACYRTATYGCACTATGTAT & PCR & & Barfuss et al., 2016 \\
\hline & $\operatorname{trn} K-2662 r$ & CTCGAACCCGGAACTAGTCGG & PCR & & Castello et al., 2016 \\
\hline & $\operatorname{mat} K 880 R$ & CCAGAAATTGACAAGGTAATATTTCC & & Seq & Duangjai et al., 2009 \\
\hline & matK1070F & CCATAGTTCCAATTATTCCTCTG & & Seq & Duangjai et al., 2009 \\
\hline & matK $1300 R$ & CGAAGTATATAYTTYATTCGATACA & & Seq & Samuel et al., 2005 \\
\hline & $\operatorname{trnK3F}$ & AGTYGGGTCKAGTRAATAAA & PCR & Seq & Pell, 2004 \\
\hline & matK $10 R$ & CGCTGTGATAATGAGAAAGA & PCR & Seq & Pell, 2004 \\
\hline
\end{tabular}


GoTaq ${ }^{\circledR}$ Flexi DNA polymerase (Promega Corporation, USA), $0.8 \mu \mathrm{L}$ of each primer $(10 \mathrm{mmol} / \mathrm{L}), 9.4 \mu \mathrm{L}$ of nuclease-free water (Promega Corporation, USA), and $5 \mu \mathrm{L}$ of DNA template were used. Applied Biosystems Veriti $^{\circledR} 96$ well Thermal Cycler (NY, USA) was used for PCR amplifications and the PCR profiles used for amplification are given in Table 3. DNA sequencing was done by a 8 capillary sequencer (Applied Biosystems, 3500 Genetic Analyzer) at the Department of Molecular Biology and Biotechnology, University of Peradeniya.

Table 3: $\quad$ PCR profile used for amplification of ITS region and matK regions

\begin{tabular}{lcccc}
\hline \multirow{2}{*}{ Process } & \multicolumn{2}{c}{ ITS region $(30$ cycles $)$} & \multicolumn{2}{c}{ matK region $(30$ cycles $)$} \\
& Temperature $(\mathrm{C})$ & Time $(\mathrm{s})$ & Temperature $\left({ }^{\circ} \mathrm{C}\right)$ & Time $(\mathrm{s})$ \\
\hline Initial denaturation & 97 & 30 & 97 & 120 \\
Denaturation & 97 & 30 & 94 & 78 \\
Annealing & 54 & 30 & $58-48$ & $120-30$ \\
Extension & 72 & 90 & 72 & 180 \\
Final extension & 72 & 420 & 72 & 900 \\
\hline
\end{tabular}

\section{Sequence alignment and phylogenetic analysis}

DNA sequences of non-native species and out group taxa were obtained from GenBank (https://www.ncbi.nlm.nih. gov/genbank/, last accessed:2017-12-04). Raw sequences were assembled, edited and processed in SeqMan Pro, DNAStar ${ }^{\circledR}$ Lasergen ver. 8.1 (DNASTAR, Inc. 2009), BioEdit ver. 7.1.9 (Hall, 1999), Muscle software (Edgar, 2004a; b) and Mesquite software ver. 3.04 (Maddison \& Maddison, 2015). Homogeneity between ITS data and plastid data was tested using the incongruence length difference (ILD) test according to Farris et al. (1995), as implemented in PAUP ver. 4.0 (Swofford, 2003).

To infer phylogenetic relationships maximum parsimony (MP), maximum likelihood (ML), and Bayesian inference (BI) were carried out. Trees were rooted with two outgroup taxa of the family Burseraceae; Bursera simaruba (L.) Sarg. and Canarium album Blanco. MP analysis was performed using PAUP* software ver. 4.0 (Swofford, 2003). For each dataset (ITS, matK and combined) heuristic search strategy was used with 1,000 replicates of random sequence addition, tree-bisection-reconnection (TBR) branch swapping and retaining multiple trees (MulTrees) by saving only 10 trees per replicate. Bootstrap method was used with full heuristic search mode followed by TBR branch swapping and random sequences addition with 1,000 replicates to estimate the support for each clade by holding only the groups with frequency greater than $50 \%$. The consistency index $(\mathrm{CI})$ and retention index (RI) for tree topologies were calculated with PAUP. ML and $\mathrm{BI}$ analyses were performed for the combined matrix. The best fitting substitution model was determined with jModelTest ver. 2.1.7 (Guindon \& Gascuel, 2003; Darriba et al., 2012) using the Akaike information criterion (AICc). Evolutionary substitution models for each marker were calculated. The generalised time reversible (GTRGAMMA) model and gamma-distributed rate variation across sites and a proportion of invariable sites were used for the analysis. The ML rapid bootstrap analysis was performed with 1,000 replicates with search for best-scoring ML tree in one run. This analysis was conducted in RAxML ver. 8.2.4 (Stamatakis, 2014). Bayesian inference was conducted to obtain posterior probabilities using MrBayes ver. 3.2.6 (Huelsenbeck \& Ronquist, 2001; Ronquist \& Huelsenbeck, 2003). The same nucleotide substitution model $(\mathrm{GTR}+\mathrm{G})$ as in $\mathrm{ML}$ analysis was used with 10,000,000 generations Markov chain Monte Carlo (MCMC) chains with a sampling frequency of every 1,000 generations. The initial $25 \%$ samples from each run were discarded as burning. A majority rule consensus tree was calculated using the remaining trees to obtain the posterior probabilities for each node. The resulting trees were visualised and edited in Fig Tree ver. 1.4 .3 (http://tree.bio.ed.ac.uk/software/ figtree/, last accessed 2017-12-04).

\section{Chromosome counts and preparation of karyotypes}

Chromosome analysis protocol of Weiss-Schneeweiss et al. (2009) was optimised for the members of family Anacardiaceae to arrest the mitotic spindles. Collected actively growing root tips were pre-treated with $0.002 \mathrm{M}$ 8 -hydroxquinoline for $2 \mathrm{~h}$ at room temperature and $2.5 \mathrm{~h}$ at $4{ }^{\circ} \mathrm{C}$. Then the root tips were fixed for $2 \mathrm{~h}$ in freshly prepared Carnoy (3:1, ethanol: acetic acid) solution and stored at $-20{ }^{\circ} \mathrm{C}$ until use. Standard Feulgen staining method was followed by washing the stored rootlets with distilled water and hydrolysing with $5 \mathrm{~N} \mathrm{HCl}$ for $30 \mathrm{~min}$. 
Root samples were washed again with distilled water and stained with colourless Schiff's reagent for $1 \mathrm{~h}$ in darkness. Prior to the squash preparation root tips were dissected and treated with lactopropionic-orcine (45\%) solution. Slides were prepared with squash technique and heat fixed. Chromosomes were examined and photographed with a binocular microscope (Zeiss Axio Lab.A1) equipped with a digital camera (Zeiss AxioCam ERc5s). Images were processed with ZEN $2012\left({ }^{\circ} \mathrm{Carl}\right.$ Zeiss Microscopy GmbH, 2011).

While preparing the karyotypes, more than three digital images were taken in different focus planes to capture the best 2D appearance of each chromosome. Karyotypes were prepared using the image processing software, Corel Photo- Paint x7 ver. 17.1.0.572 ( ${ }^{\circ} 2014$ Corel Corporation) by arranging homologous pairs of chromosomes based on descending order of their sizes.

\section{RESULTS AND DISCUSSION}

\section{Statistics of data matrixes and phylogenetic trees}

This study mainly focused on combining the molecular and cytological data of regionally restricted endemic and native Anacardiaceae species of Sri Lanka. Out of 15 endemics, nine species and one native taxon were included in this study. All these species were investigated for the first time at molecular and cytological level. Extensive field investigations were carried out throughout the country and most of the species were found at the Kanneliya Man and Biosphere Reserve (Ariyarathne et al., 2017). Some species were declared as Critically Endangered Possibly Extinct [CR(PE)] due to the inability to locate in the wild (MOE, 2012).

Length variations were observed among sequences in both ITS (rDNA) and matK datasets. Nuclear ITS dataset is composed of 33 ingroup taxa while that of matK contains 31 taxa, which includes nine endemic and a native taxon from Sri Lanka. Statistics and data characteristics from the maximum parsimony analysis of both gene regions and the combined datasets are given in Table 4.

Phylogenetic analysis of ITS, matK and combined data matrices

Maximum parsimony analysis of ITS data matrix revealed that the family Anacardiaceae is monophyletic. Within this super clade, a large clade is formed by species belong to the subfamily Anacardioideae whereas species of subfamily Spondioideae remain paraphyletic together with the genus Campnosperma. Two major clades of tribe Anacardieae and tribe Semecarpeae show weak bootstrap support. Most of the relationships between the species belonging to the tribe Rhoeae remain unresolved. The MP analysis of the matK matrix resulted in congruent topologies to that of the ITS. It also revealed the monophyly of the family Anacardiaceae. The subfamily Anacardioideae forms a monophyletic super clade and tribe Ancardieae forms a monophyletic subclade. Sri Lankan endemic Semecarpus species build a monophyletic group of tribe Semecarpeae while nonnative Semecarpus species are paraphyletic.

Table 4: Statistics and data characteristics from the maximum parsimony analysis of both gene regions and the combined datasets.

\begin{tabular}{lccc}
\hline & ITS & mat $\boldsymbol{K}$ & Combined \\
\hline Total number of taxa & 33 & 31 & 35 \\
Number of Sri Lankan taxa & 10 & 10 & 10 \\
Number of ingroup taxa & 31 & 29 & 33 \\
Number of outgroup taxa & 2 & 2 & 2 \\
Total characters & 1,000 & 2,251 & 3,250 \\
Number of variable characters (\%) & $451(45 \%)$ & $348(15.5 \%)$ & $799(24.5 \%)$ \\
Number of parsimony informative characters (\%) & $274(27.4 \%)$ & $117(5.2 \%)$ & $391(12 \%)$ \\
Number of equally parsimonious trees & 5,810 & 9,970 & 24 \\
Tree length & 1547 & 493 & 1975 \\
Consistency index & 0.473 & 0.554 & 0.563 \\
Retention index & 0.507 & 0.667 & 0.567 \\
\hline
\end{tabular}






Figure 1: Best-scoring maximum likelihood tree of the combined dataset. Posterior probabilities obtained from BI (PP-BI), bootstrap percentages ( $>50 \%$ ) of MP (BS-MP) and ML (BS-ML) analyses are denoted and separated by a slash. Hyphens indicate the PP-BI $<0.5$ and BS-MP/ BS-ML $<50 \%$. Sri Lankan species are indicated with bold letters and an '*'. Colours and vertical lines indicate the allocation of species in present classification system.

The resulting trees of the combined matrix (Figures1 and 2) analysed with all three phylogenetic inference methods (MP, ML and BI) were congruent for the major clades. The family Anacardiaceae resolved as a monophyletic super clade [posterior probability (PPBI): 1/ MP bootstrap values (BS-MP): 100/ ML bootstrap values (BS-ML): 100]. This order is used throughout the text. Within this, the subfamily Anacardioideae form a major clade comprising of subclades representing three tribes Semecarpeae (0.71/57/73), Anacardieae (1/92/91) and non-monophyletic Rhoeae. Non-native T. acuminata is separated from the other members of the Rhoeae and clusters together with Semecarpeae. Further, the endemic Campnosperma zeylanica of Rhoeae resolved as the basal taxa, close to the paraphyletic subfamily Spondioideae. The best-scoring maximum likelihood tree of the combined dataset (Figure 1) and the $50 \%$ majority rule consensus tree (Figure 2) resulting from Bayesian inference are shown. 


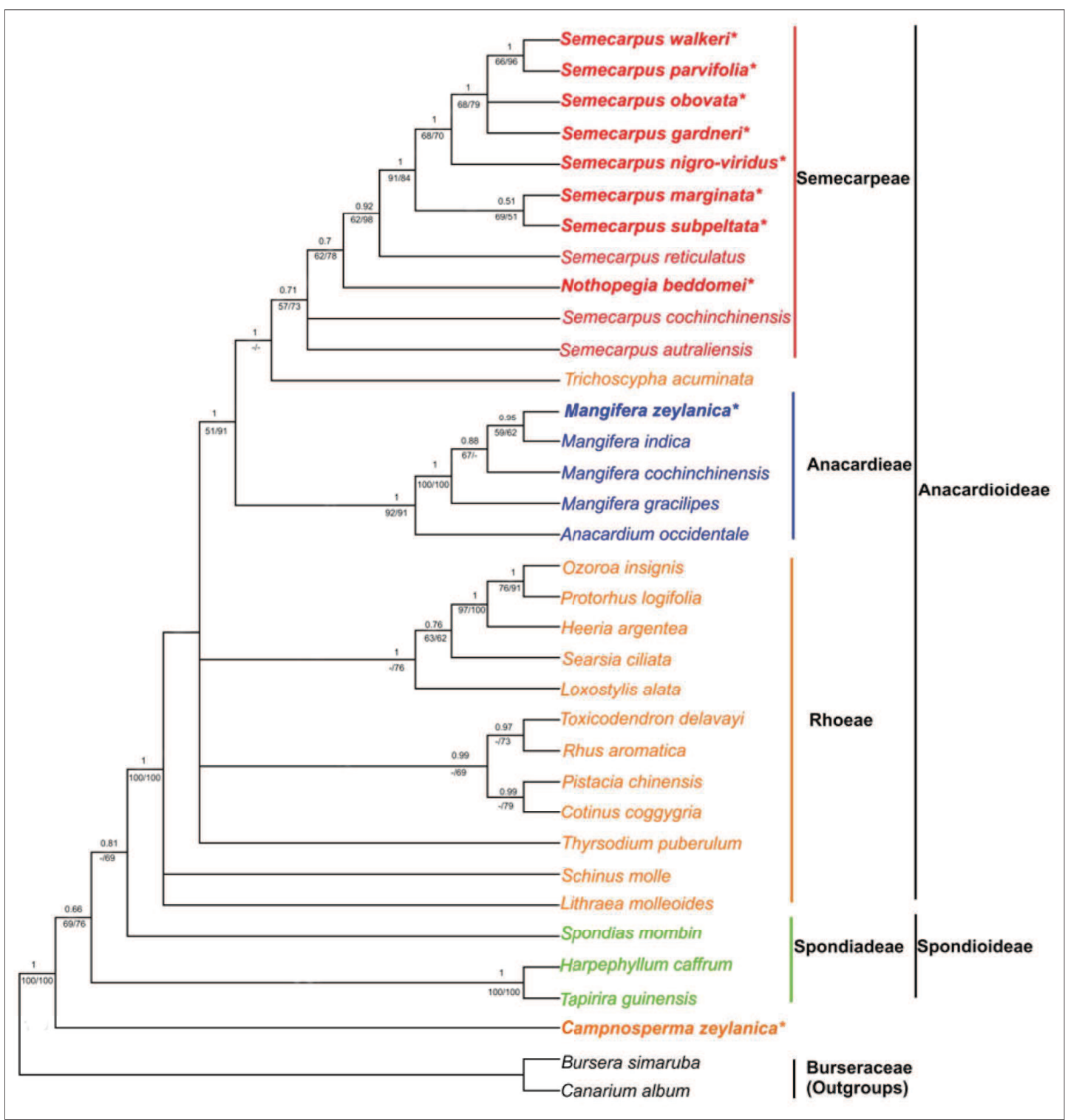

Figure 2: $\quad$ Majority rule (50\%) consensus tree obtained from Bayesian inferences for the combined matrix of nuclear ITS and $m a t K$ datasets. Posterior probabilities (PP-BI $>0.5$ ) are given above the nodes. Bootstrap percentages $(>50 \%)$ of maximum parsimony (BS-MP) and maximum likelihood are indicated below the nodes separated by a slash. Hyphen indicates the bootstrap values less than $50 \%$. Sri Lankan species are indicated with bold letters and an '*'. Colours and vertical lines indicate the allocation of species in present classification system.

\section{Phylogenetic relationships in Anacardiaceae}

The family Anacardiaceae forms a large monophyletic group with strong support $(1 / 100 / 100)$. One of the main aims of this investigation was to clarify the phylogenetic positions of Sri Lankan endemic species of Anacardiaceae. Within the subfamily Anacardioideae, all the endemic taxa including Mangifera zeylanica and Semecarpus species are well resolved in their subfamilial and tribal positions. The native species Nothopegia beddomei is placed in tribe Semecarpeae indicating its close relationship to genus Semecarpus. The non-native 
species of Trichoscypha acuminata, which was assigned to tribe Rhoeae based on morphological characters is found in close relation within the tribe Semecarpeae with weak support. The clade of tribe Semecarpeae is resolved with weak bootstrap and posterior support (0.71/57/73). Semecarpus australiensis and S. cochinchinensis resolve as basal taxa in this clade. Nothopegia beddomei (the native species used in this study) and $S$. reticulatus are positioned outside the major subclade formed by the Sri Lankan endemic Semecarpus species with strong support (1/91/84). Semecarpus walkeri and $S$. parvifolia show a close relationship with strong support (1/66/96). Semecarpus obovata and S. gardneri have resolved outside to $S$. walkeri and $S$. parvifolia with weak support forming an inner clade. Semecarpus nigro-viridis shows sister relationship to this inner clade with moderate support (1/68/70). Semecarpus marginata and $S$. subpeltata also exhibit close affinity with a weak support of $0.51 / 69 / 51$. Within the tribe Anacardieae, subclade of genus Mangifera is strongly supported (1/100/100) compared to the subclade that contains A. occidentale (1/92/91). Mangifera zeylanica shows close relationship to $M$. indica than other species used in this study. However, the relationship is weakly supported (0.95/59/62). Tribe Rhoeae has formed a weakly supported clade. Many nodes of this clade are not resolved in maximum parsimony analysis but there are a few resolved nodes with the Bayesian inference. The endemic species Campnosperma zeylanica, which has been allocated to the subfamily Anacardioideae clusters with subfamily Spondioideae. This species has resolved as basal taxa for the family Anacardiaceae in all three phylogenetic analyses with weak support (0.66/69/76). The species belonging to the subfamily Spondioideae, tribe Spondiadeae has formed a paraphyletic clade with strongly supported subclade (1/100/100).

Several researchers (Wannan \& Quinn, 1991; Terraza, 1994; Takhtajan, 1997; Pell, 2004; Mitchell et al., 2006) have tried to solve the ambiguities in the classification and phylogeny of the family Anacardiaceae. This attempt was made to understand the phylogenetic position of Sri Lankan endemic Anacardiaceae species and to look into chromosomal evolution of these endemics. All the Sri Lankan endemic species have been well placed in their corresponding taxonomic positions except for Campnosperma zeylanica. Phylogenies constructed for all three datasets (ITS, matK, and combined) support the placement of endemic species in the tribes Anacardieae and Semecarpeae, having C. zeylanica as a basal taxon.

As per the systematic history of the family Anacardiaceae, genus Campnosperma had been taxonomically problematic. Wannan and Quinn (1991) tried to treat genus Campnosperma taxonomically by assigning it in 'Group B' as per their classification together with species of Spondiadeae and three other genera of tribe Anacardieae and Rhoeae.

Family Anacardiaceae was reported to be paraphyletic (Terrazas, 1994) with Burseraceae nested within the cashew family, sister to tribe Spondiadeae. However, the combined analysis of $r b c L$ and morphological data suggested monophyly of family Anacardiaceae (Terrazas, 1994) with similar grouping as suggested by Bentham and Hooker (1862) and Wannan and Quinn (1991), having genus Campnosperma within subfamily Anacardioideae. Since then this genus has remained as a member of subfamily Anacardioideae.

Lepidote scales are very rare in the family Anacardiaceae but is characteristic of the genus Campnosperma. These scales are similar to that found in genus Tapirira (Tapirira lepidota Aguilar \& Hammel), which is a member of subfamily Spondioideae (Hammel et al., 2014). In Anacardiaceae, stigmas are usually capitate and ovary 1-locular. However, Campnosperma contain bi-locular ovaries whereas almost all the species of subfamily Spondioideae are composed of more than one locular. Genus Campnosperma together with genus Pegia Coleb. contain discoid stigmas. Other than these, members of this genus share the tribal (Spondiadeae) characters of having spondias-type endocarp as categorised by Wannan and Quinn (1990), partially pachychalazal seeds, stilt roots and polygamodiocious plants. Therefore, the placement of this genus in subfamily Anacardioideae has been highly controversial; however, the present study corroborates with the placement of genus Campnosperma in the subfamily Spondioideae. This placement could be further supported by additional taxa from other regions.

Pell (2004), built a phylogeny of Anacardiaceae with matK plastid DNA sequences. In this investigation, 33 taxa belonging to the five tribes of the family Anacardiaceae and five species of the outgroup family Burseraceae were used. The tree topologies of the present study agree with the phylogenetic tree constructed by Pell (2004), which shows a close relationship between the tribes Semecarpeae and Anacardieae that form a clade, as well as paraphyly of the subfamily Spondioideae.

The position of the displaced non-native species of $T$. acuminata also remains questionable, but since the sequences were obtained from GenBank, errors in plant identification and processing cannot be excluded. Therefore, further investigations have to be carried out to find the exact place of this species in the phylogenetic 
Table 5: Chromosome numbers of the endemic species together with the size, types and numbers of chromosomes in each karyotype

\begin{tabular}{lccl}
\hline Species & $2 n=2 x$ & Size $(\mu \mathrm{m})$ & Types of chromosomes (number) \\
\hline Mangifera zeylanica & 42 & $1-3$ & $\begin{array}{l}\text { Metacentric (6), Submetacentric (10), } \\
\text { Acrocentric (3), Telocentric (2) }\end{array}$ \\
$\begin{array}{l}\text { Semecarpus marginata } \\
\text { (Figure 3A, 3B) }\end{array}$ & 58 & $1-4$ & $\begin{array}{l}\text { Metacentric (14), Submetacentric (7), } \\
\text { Acrocentric (3), Telocentric (5) }\end{array}$ \\
$\begin{array}{l}\text { Semecarpus nigro-viridis } \\
\text { (Figure 3C, 3D) }\end{array}$ & 56 & $0.5-2$ & $\begin{array}{l}\text { Metacentric (13), Submetacentric (10), } \\
\text { Telocentric (5) }\end{array}$ \\
$\begin{array}{l}\text { Semecarpus obovata } \\
\text { (Figure 3E, 3F) }\end{array}$ & 52 & $1.5-4.5$ & $\begin{array}{l}\text { Metacentric (13), Submetacentric (10), } \\
\text { Telocentric (3) }\end{array}$ \\
Semecarpus parvifolia & 50 & $0.5-1.5$ & $\begin{array}{l}\text { Metacentric (3), Submetacentric (11), } \\
\text { Acrocentric (5), Telocentric (6) }\end{array}$ \\
& & &
\end{tabular}

tree by including properly identified and sequenced individuals in the analyses.

\section{Chromosome numbers and karyotypes in Anacardiaceae}

Chromosomes numbers of five endemic Anacardiaceae species are reported for the first time given in the Table 5 and Figure 3. Chromosome numbers obtained during this study together with the previously published reports are given in the Table 6.

\section{Phylogeny and chromosomal evolution}

Recent advances in molecular biology has allowed more precise evaluation of the importance of polyploidy in flowering plant evolution with most, if not all, plants being of ancient paleopolyploid origin (Soltis et al., 2009; Du et al., 2012; Li et al., 2015). With the recent developments in the field, the most appropriate way of estimating chromosome numbers in phylogenetic trees is by using ancestral character reconstruction software like ChromEvol and Chromploid. However, the applicability of these software for the present dataset was not possible due to the lack of cytological data of foreign taxa. Thus, the chromosomal numbers obtained in this study and counts from the literature survey (Table 6) were manually mapped to the phylogeny obtained from the combined matrix to elucidate the chromosomal evolution of this family (Figure 4).

The two out group taxa of Burseraceae show chromosome numbers of $2 n=24$ and $2 n=48$, which supports the polyploidy within the family. Chromosome numbers of the family Anacardiaceae ranges from $2 n=$ 24 to $2 n=58$. Among these, most of the species belong to the tribe Rhoeae recorded $2 n=30$ with the exception of $S$. molle and $P$. chinensis with chromosome numbers $2 n=24$ and 28 , respectively.

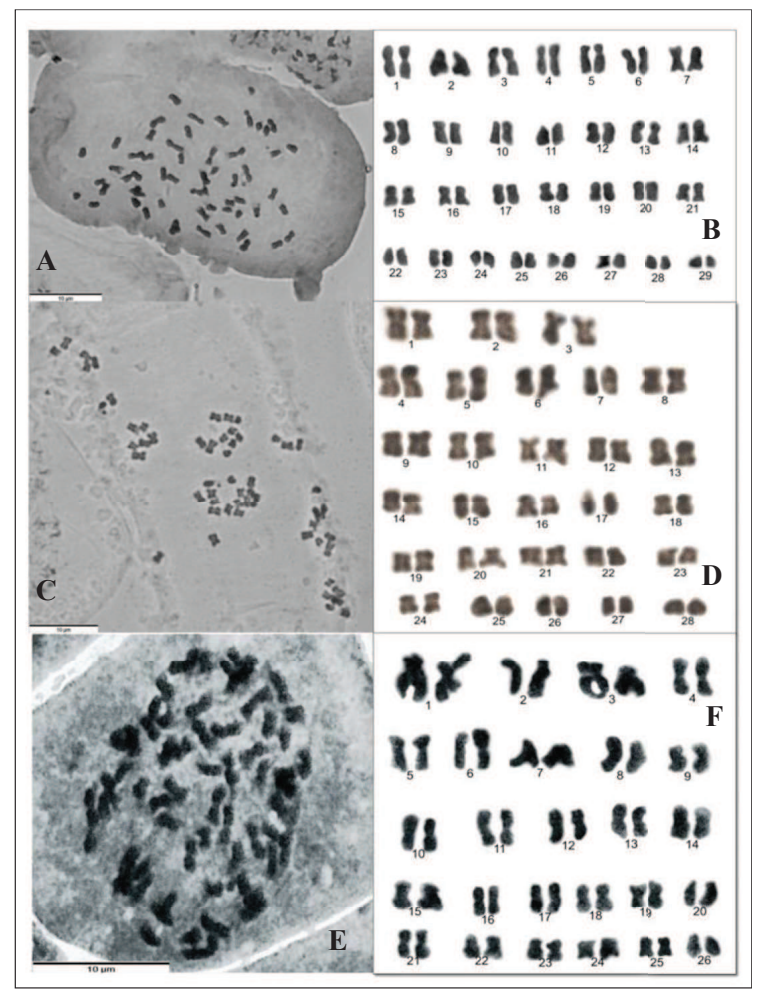

Figure 3: Chromosome spreads and karyotypes of Semecarpus species. A - S. marginata chromosome spread $(2 n=58)$; B - Karyotype of $S$. marginata; C - S. nigroviridis chromosome spread $(2 n=56)$; D - Karyotype of S. nigro-viridis E - S. obovata chromosome spread $(2 n=$ 52); F - Karyotype of S. obovata. Scale bar $=10 \mu \mathrm{m}$. 
Table 6: Accession numbers for the species downloaded from GenBank together with reported chromosome numbers with references and the putative ploidy levels are given. Species that were studied for the first time indicated in bold letters and the ' $*$ ' indicates the endemic species of Sri Lanka. Accession numbers marked with 'NA' were not included in the corresponding matrixes.

\begin{tabular}{|c|c|c|c|c|c|}
\hline \multirow[t]{3}{*}{ Species Name } & \multicolumn{2}{|c|}{ GenBank Accession Number } & \multirow{3}{*}{$\mathrm{CN}(2 n)$} & \multicolumn{2}{|c|}{ Chromosomal Studies } \\
\hline & ITS & matK & & Putative & Reference(s) \\
\hline & & & & Ploidy level & \\
\hline Anacardium occidentale $\mathrm{L}$. & KF664192.1 & AY594459.1 & 42 & $2 x$ & Aliyu \& Awopetu (2007) \\
\hline Cotinus coggygria Scop. & AY510157.1 & HE966907.1 & 30 & $2 x$ & $\begin{array}{l}\text { Vladimirov \& Dimitrova } \\
\text { (2007) }\end{array}$ \\
\hline Harpephyllum caffrum Bernh. & KF664197.1 & JF270814.1 & - & - & - \\
\hline Heeria argentea Meisn. & AY594378.1 & JX518129.1 & - & - & - \\
\hline Lithraea molleoides (Vell.) Engl. & KF420989.1 & KF555405.1 & 30 & $2 x$ & Coleman (1982) \\
\hline Loxostylis alata A. Spreng. ex Rchb. & AY531201.1 & JX517988.1 & - & - & - \\
\hline Mangifera cochinchinensis Engl. & AB071676.1 & AB924713.1 & - & - & - \\
\hline Mangifera gracilipes Hook.f. & AB071686.1 & NA & - & - & - \\
\hline Mangifera indica $\mathrm{L}$. & KF664199.1 & AY594472.1 & 40 & $2 x$ & Pierozzi \& Rossetto (2006) \\
\hline Ozoroa insignis Delile & AY594381.1 & KX146378.1 & - & - & - \\
\hline Pistacia chinensis Bunge & EF193080.1 & NA & 24 & $2 x$ & Huang et al. (1989) \\
\hline Protorhus longifolia (Bernh.) Engl. & EF089146.1 & JX517542.1 & - & - & - \\
\hline Rhus aromatica Aiton & AY641494.1 & AY594494.1 & 30 & $2 x$ & $\begin{array}{l}\text { Parfitt et al. (1990), Yi et al. } \\
\text { (2007) }\end{array}$ \\
\hline Schinus molle $\mathrm{L}$. & AY641512.1 & JX517745.1 & 28 & $2 x$ & Oginuma et al. (1993) \\
\hline Searsia ciliata (Licht. ex Schult.) A.J.Mill. & AY 641513.1 & KX146267.1 & - & - & - \\
\hline Semecarpus australiensis Engl. & NA & AY594479.1 & - & - & - \\
\hline Semecarpus cochinchinensis Engl. & NA & AB925248.1 & - & - & - \\
\hline Semecarpus reticulatus Lecomte & KR532565.1 & NA & - & - & - \\
\hline Spondias mombin $\mathrm{L}$. & AF445882.1 & KP774611.1 & 30 & $2 x$ & $\begin{array}{l}\text { Vladimirov \& Dimitrova } \\
\text { (2007) }\end{array}$ \\
\hline Tapirira guianensis Aubl. & DQ787402.1 & KF981295.1 & - & - & - \\
\hline Thyrsodium puberulum J.D. Mitch. \& D.C. Daly & FJ037790.1 & FJ514723.1 & - & - & - \\
\hline Toxicodendron delavayi (Franch.) F.A. Barkley & FJ945937.1 & NA & - & - & - \\
\hline Trichoscypha acuminata Engl. & AY594389.1 & KC627761.1 & - & - & - \\
\hline Bursera simaruba (L.) Sarg. (Outgroup) & GQ378130.1 & KJ772596.1 & 24 & $2 x$ & Fedorov (1969) \\
\hline Canarium album (Lour.) DC. (Outgroup) & DQ517524.1 & KJ510921.1 & 48 & $2 x$ & Chen et al. (1993) \\
\hline${ }^{*}$ Campnosperma zeylanica Thw. & MG672041 & MG787233 & - & - & - \\
\hline *Mangifera zeylanica (Blume) Hook.f. & MG672042 & MG787234 & 42 & $2 x$ & Present study \\
\hline *Semecarpus marginata Thw. & MG672044 & MG787237 & 58 & $2 x$ & Present study \\
\hline *Semecarpus gardneri Thw. & MG672043 & MG787236 & - & - & - \\
\hline${ }^{*}$ Semecarpus nigro-viridis Thw. & MG672045 & MG787238 & 56 & $2 x$ & Present study \\
\hline *Semecarpus obovata Moon & MG672046 & MG787239 & 52 & $2 x$ & Present study \\
\hline *Semecarpus parvifolia Thw. & MG672047 & MG787240 & 50 & $2 x$ & Present study \\
\hline *Semecarpus subpeltata Thw. & MG672048 & MG787241 & - & - & - \\
\hline *Semecarpus walkeri Hook.f. & MG672049 & MG787242 & - & - & - \\
\hline Nothopegia beddomei Gamble & MG672050 & MG787235 & - & - & - \\
\hline
\end{tabular}




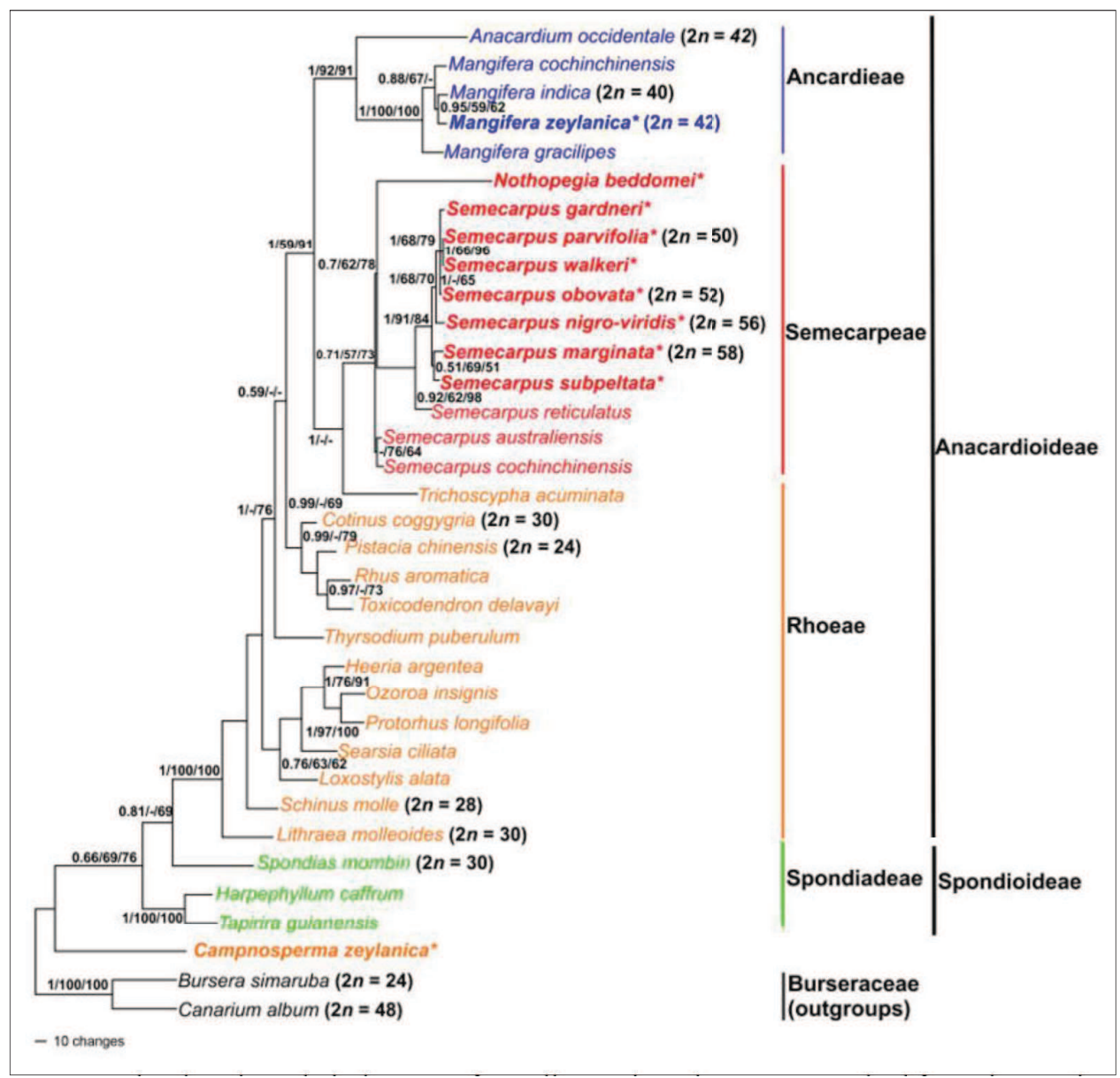

Figure 4: Randomly selected phylogram of equally parsimonious trees resulted from the maximum parsimony analysis of the combined dataset. Posterior probabilities obtained from BI (PP-BI > 0.5), bootstrap percentages $(>50 \%)$ of MP (BS-MP) and ML (BS-ML) analyses are denoted and separated by a slash. Hyphens indicate the PP-BI $<0.5$ and BS-MP/ BS-ML $<50 \%$. Sri Lankan species investigated during the present study are indicated with bold letters and an '*'. Colours and vertical lines indicate the allocation of species in present classification system. Chromosomal counts are given at the end of node labels.

Chromosome numbers of species belonging to the tribe Anacardieae vary between $2 n=40$ and $2 n=42$. Previous investigations have concluded the diploid number of $M$. indica as $2 n=40$ (Mukherjee \& Ammal, 1955; Darlington, 1950; 1957; Pierozzi \& Rossetto, 2006). In the present investigation, chromosome count for the endemic species $M$. zeylanica is $2 n=42$ (Figure 3 ). This could be due to dysploidy when compared with M. indica. Chromosome counts of endemic Semecarpus species in tribe Semecarpeae increase from $2 n=50$ to 58 through the subclade suggesting speciation through dysploidy events. The range of the chromosome numbers obtained in this study agree with available counts in the literature for genus Semecarpus as $n=29,30$ (Mehra, 1976; Gill et al., 1981; 1990; Bir et al., 1982; Singhal \& Gill, 1990; Pell et al., 2010) and $2 n=60$ (Hou, 1978).

According to Raven (1975) and Lewis (2012) the common basic numbers of the family Anacardiaceae are $x=14,15$, and 16 with a few exceptions; genera, Mangifera $(x=20)$, Ancardium $(x=21)$ and several genera with $x=12$. They justify the hypothetical basic number of the family Anacardiaceae as $x=7$, which gave rise to tetraploidy in most of the taxa. The two 
main mechanisms of chromosomal evolution, dysploidy (increasing or decreasing) and polyploidy have been suggested by previous investigators (Escudero et al., 2014; Mota, 2014). The present study emphasises polyploidy in the evolution of Anacardiaceae. However, the pattern of chromosome number change along the phylogenetic tree indicates increasing dysploidy. According to Wendel (2000), $70 \%$ of angiosperms are considered to be polyploids including most of Anacardiaceae species.

Polyploidy has been a key mechanism driving the evolution of angiosperms with great rarity of reduction of polyploidy levels back to diploids.

Raven (1975) suggested that diploid level has been the main pathway of vascular plant evolution and the diploids have given rise to polyploids under number of circumstances. Polyploidy also has an effect on decreased diversification rate (Escudero et al., 2014). According to Osborn et al. (2003), species that have undergone either polyploidy or dysploidy often tend to demonstrate phenotypic deviation from their diploid ancestors. These new traits might play a role in natural selection process. Some of these traits such as increased apomixis, pest resistance, drought tolerance, flowering periods, and fruit and leaf size could offer higher chances in survival, and thus being selected as economic crops (Osborn et al., 2003).

The mechanisms that drive polyploidy is not yet fully understood but reasonably assumed that the adaptive neofunctionalization process in effect with mutating/ duplicating genes have relaxed constraints on their function, thus diverging to new phenotypes (Osborn et al., 2003).

Future comprehensive and collaborative molecular and cytological studies would reveal the driving force of polyploidy through the evolutionary pathway as this study explored the phylogenetic positions and chromosomal evolution of Sri Lankan endemic Anacardiaceae species.

\section{CONCLUSION}

Several taxonomic treatments based on anatomical, morphological, phytochemical and molecular data have been carried out in the past focusing on the phylogeny of the family Anacardiaceae. However, native and endemic Anacardiaceae flora of Sri Lanka yet remained understudied. This is the first molecular phylogenetic study, including representatives from all genera having endemic species of the family Anacardiaceae from
Sri Lanka. This study resolves the monophyly of the family Anacardiaceae, while recovering the paraphyly of the two subfamilies Anacardioideae and Spondioideae with the questionable placement of taxa belonging to the subfamily Anacardioideae. The present study also questions the phylogenetic placement of genus Campnosperma. Cytological evolution of the family shows the major dysploidy events. Certain genera, such as Campnosperma and Nothopegia are needed to be further investigated with increased sampling including pantropical species and utilising more molecular markers. Chromosome evolutions of different families need to be investigated to reveal the evolutionary scenarios.

\section{Acknowledgment}

The authors thank Mr. A.M.T.K Bandara, Mr. Y.S. Athugala, Mr. P. Karunarathne, Ms. C.G. Manawaduge and Ms. N. Silva for their valuable support during field work, Department of Wildlife Conservation, Forest Department of Sri Lanka and the National Herbarium, Royal Botanic Gardens for providing necessary permissions and guidance. This research was financially supported by the National Research Council of Sri Lanka (NRC 12-121).

\section{REFERENCES}

Aliyu O.M. \& Awopetu J.A. (2007). Chromosome studies in cashew (Anacardium occidentale L.). African Journal of Biotechnology 6: 131-136.

Almeida C.C., De Lemos Carvalho P.C. \& Guerra M. (2007). Karyotype differentiation among Spondias species and the putative hybrid Umbu-cajá (Anacardiaceae). Botanical Journal of the Linnean Society 155: 541-547. DOI: https://doi.org/10.1111/j.1095-8339.2007.00721.x

Ariyarathne W.A.M.P., Yakandawala D., Samuel M.R. \& Wijesundara S. (2017). Evaluating the occurrence and conservation status of Sri Lankan species of Anacardiaceae. Ceylon Journal of Science 46: 59-67.

DOI: https://doi.org/10.4038/cjs.v46i2.7430

Barfuss M.H.J., Till W., Leme E.M.C., Pinzón J.P., Manzanares J.M., Halbritter H., Samuel R. \& Brown G.K. (2016). Taxonomic revision of Bromeliaceae subfam. Tillandsioideae based on a multi-locus DNA sequence phylogeny and morphology. Phytotaxa 279: 1-97. DOI: https://doi.org/10.11646/phytotaxa.279.1.1

Bateman R.M., Hollingsworth P.M., Preston J., Yi-Bo L., Pridgeon A.M. \& Chase M.W. (2003). Molecular phylogenetics and evolution of Orchidinae and selected Habenariinae (Orchidaceae). Botanical Journal of the Linnean Society 142: 1-40. DOI: https://doi.org/10.1046/j.1095-8339.2003.00157.x

Bentham G. \& Hooker J.D. (1862). Anacardiaceae. In: Genera Plantarum 1, pp. 415-428. Reeve and Company, London, UK. 
Bir S.S., Gill B.S., Bedi Y.S. \& Singhal V.K. (1982). Evolutionary status of the woody taxa of Garhwal Himalaya. In: Improvement of Forest Biomass: Symposium Proceedings, Indian Council of Agriculture Research (ed. P. K. Khosla), pp. 81-96. Indian Society of Tree Scientists, Solan, India.

Castello L.V., Barfuss M.H.J., Till W., Galetto L. \& Chiapella J.O. (2016). Disentangling the Tillandsia capillaris complex: phylogenetic relationships and taxon boundaries in Andean populations. Botanical Journal of the Linnean Society 181: 391-414.

DOI: https://doi.org/10.1111/boj.12400

Chase M.W. \& Hills H.G. (1991). Silica gel: an ideal material for field preservation of leaf samples for DNA studies. Taxon 40: 215-220. DOI: https://doi.org/10.2307/1222975

Chen R.Y., Song W.Q. Liang G.L., Lin S.H., Li X.L. \& An Z.P. (1993). Chromosome atlas of Chinese principal economic plants, In: Chromosome Atlas of Chinese Fruit Trees and their Close Wild Relatives, pp. xxiv-619. International Academic Publishers, Beijing, China.

Coleman J.R. (1982). Chromosome numbers of Angiosperms collected in the state of Sao-Paulo. Revista Brasileira de Genética 5(3): 533-549.

Cox A., Abdelnour G., Bennett M. \& Leitch I. (1998). Genome size and karyotype evolution in the slipper orchids (Cypripedioideae: Orchidaceae). American Journal of Botany 85: 681-681.

DOI: https://doi.org/10.2307/2446538

Darlington C.D. \& Ammal E.K.J. (1955). Chromosome Atlas of Cultivated Plants. George Allen and Unwin Limited, London, UK.

Darriba D., Taboada G.L., Doallo R. \& Posada D. (2012). jModel-Test 2: more models, new heuristics and parallel computing. Nature Methods 9: 772.

DOI: https://doi.org/10.1038/nmeth.2109

Du J., Tian Z., Sui Y., Zhao M., Song Q., Cannon S.B., Cregan P. \& Ma J. (2012). Pericentromeric effects shape the patterns of divergence, retention, and expression of duplicated genes in the paleopolyploid soybean. The Plant Cell 24(1): 21-32.

DOI: https://doi.org/10.1105/tpc.111.092759

Duan Y., Zhu B., Shu S., Li Z. \& Wang M. (2015). Karyotypes and fish detection of $5 \mathrm{~S}$ and $45 \mathrm{~S}$ rDNA loci in Chinese medicinal plant Atractylodes lancea subsp. luotianensis: cytological evidence for the new taxonomic unit. Pakistan Journal of Botany 47: 103-107.

Duangjai S., Samuel R., Munzinger J., Forest F., Wallnöfer B., Barfuss M.H.J., Fischer G. \& Chase M.W. (2009). A multilocus plastid phylogenetic analysis of the pantropical genus Diospyros (Ebenaceae), with an emphasis on the radiation and biogeographic origins of the New Caledonian endemic species. Molecular Phylogenetics and Evolution 52: 602-620.

DOI: https://doi.org/10.1016/j.ympev.2009.04.021

Edgara R.C. (2004a). MUSCLE: multiple sequence alignment with high accuracy and high throughput. Nucleic Acids Research 32: 1792-1797.

DOI: https://doi.org/10.1093/nar/gkh340
Edgarb R.C. (2004b). MUSCLE: a multiple sequence alignment method with reduced time and space complexity. $B M C$ Bioinformatics 5: 113.

Eichler A.W. (1875-78). Flower Diagrams Constructed and Explained, volume 1 and 2. Wilhelm Engelmann, Leipzig, Germany.

Engler A. (1881). Über die morphologischen verhältnisse und die geographische verbreitung der gattung Rhus, wie der mit ihr verwandten, lebenden und ausgestorbenen Anacardiaceae. Botanische Jahrbücher für Systematik Pflangengeschichte und Pflanzengeographie 1: 365-426.

Engler A. (1883). Anacardiaceae. In: Monographie Phanerogamarum 4 (eds. A.P. De Candolle \& A.C. De Candolle), pp. 171-546. G. Masson, Paris, France.

Engler A. (1892). Anacardiaceae. In: Die natürlichen pflanzenfamilien III, 5. (eds. A. Engler \& K. Prantl), pp. 138-17. W. Engelmann, Leipzig, Germany.

Escudero M., Martín-Bravo S., Mayrose I., FernándezMazuecos M., Fiz-Palacios O., Hipp A.L., Pimentel M., Jiménez-Mejías P., Valcárcel V., Vargas P. \& Luceño M. (2014). Karyotypic changes through dysploidy persist longer over evolutionary time than polyploid changes. PloS One 9: 1-7. DOI: https://doi.org/10.1371/journal.pone.0085266

Farris J.S., Källersjö M. Kluge A.G. \& Bult C. (1995). Constructing a significance test for incongruence. Systematic Biology 44: 570-572.

DOI: https://doi.org/10.1093/sysbio/44.4.570

Fedorov A. (ed.) (1969). Chromosome Numbers of Flowering Plants, Academy of Science of U. S.S.R., Leningrad, Russia.

Gentry A.H. (1982). Neotropical floristic diversity: phytogeographical connections between Central and South America, Pleistocene climatic functions, or an accident of the Andean orogeny? Annals of the Missouri Botanical Garden 69: 557-593.

DOI: https://doi.org/10.2307/2399084

Gill B.S., Bir S.S. \& Singhal V.K. (1981). Chromosome number reports LXXI. Taxon 30: 513-514.

DOI: https://doi.org/10.1002/j.1996-8175.1981.tb00780.x

Gill B.S., Singhal V.K., Bedi Y.S. \& Bir S.S. (1990). Cytological evolution in the woody taxa of Pachmarhi Hills. Journal of Cytology and Genetics 25: 308-320.

Guindon S. \& Gascuel O. (2003). A simple, fast and accurate method to estimate large phylogenies by maximumlikelihood. Systematic Biology 52: 696-704. DOI: https://doi.org/10.1080/10635150390235520

Hall T.A. (1999). BioEdit: a user-friendly biological sequence alignment editor and analysis program for windows 95/98/ NT. Nucleic Acids Symposium Series 41: 95-98.

Hammel B.E., Grayum M.H. \& Aguilar R. (2014). Tapirira lepidota (Anacardiaceae), a unique new species from the Golfo Dulce region of Costa Rica. Phytoneuron 10: 1-5.

Hansen A.K., Gilbert L.E., Simpson B.B., Downie S.R., Cervi A.C. \& Jansen R.K. (2006). Phylogenetic relationships and chromosome number evolution in Passiflora. Systematic Botany 31: 138-150.

DOI: https://doi.org/10.1600/036364406775971769 
Hou D. (1978). Florae Malesianae praecursores LVI. Anacardiaceae. Blumea-Biodiversity, Evolution and Biogeography of Plants 24: 1-41.

Hsu J. (1983). Late Cretaceous and Cenozoic vegetation in China, emphasizing their connections with North America. Annals of the Missouri Botanical Garden 70(3): 490-508. DOI: https://doi.org/10.2307/2992084

Huang S.F., Zhao Z.F., Chen Z.Y., Chen S.J. \& Huang X.X. (1989). Chromosome counts on one hundred species and infraspecific taxa. Acta Botanica Austro Sinica 5: 161-176.

Huelsenbeck J.P. \& Ronquist F. (2001). MRBAYES: Bayesian inference of phylogenetic trees. Bioinformatics 17: 754-755.

DOI: https://doi.org/10.1093/bioinformatics/17.8.754

Koch M.A., Kiefer M., German D.A., Al-Shehbaz I.A., Franzke A., Mummenhoff K. \& Schmickl, R. (2012). BrassiBase: Tools and biological resources to study characters and traits in the Brassicaceae-version 1.1. Taxon 61(5): 1001-1009. DOI: https://doi.org/10.1002/tax.615007

Lewis W.H. (ed.) (2012). Polyploidy: Biological Relevance, volume 13. Springer Science and Business Media, Berlin, Germany.

Li J. (2007). Flora of China. Harvard Papers in Botany 13: 301-302.

Li Z., Baniaga A.E., Sessa E.B., Scascitelli M., Graham S.W., Rieseberg L.H. \& Barker M.S. (2015). Early genome duplications in conifers and other seed plants. Science Advances 1(10): 1-7.

DOI: https://doi.org/10.1126/sciadv.1501084

Lindley J. (1830). An introduction to the Natural System of Botany. Longman, Rees, Orme, Brown and Green, London, England.

Maddison W.P. \& Maddison D.R. (2015). Mesquite: a modular system for evolutionary analysis. ver. 3.04. 2015. Available at http://mesquiteproject.org, Accessed 04 December 2017.

Maheshwari P. (1934). The Indian mango. Current Science 3: 97-98.

Marchand N.L. (1869). Révision du Groupe des Anacardiacées. J.B. Bailliére and Sons, Paris, France.

Mayrose I., Barker M.S. \& Otto S.P. (2009). Probabilistic models of chromosome number evolution and the inference of polyploidy. Systematic Biology 59(2): 132-144. DOI: https://doi.org/10.1093/sysbio/syp083

Mehra P.N. (1976). Cytology of Himalayan Hardwoods. Sree Saraswaty Press, Calcutta, India.

Ministry of Environment (MOE) (2012). The National Red List 2012 of Sri Lanka; Conservation Status of the Fauna and Flora, pp. viii-476. Ministry of Environment, Colombo, Sri Lanka.

Mitchell J.D. \& Mori S.A. (1987). The cashew and its relatives (Anacardium: Anacardiaceae). Memoirs of the New York Botanical Garden 42: 1-76.

Mitchell J.D., Daly D.C., Pell S.K. \& Randrianasolo A. (2006). Poupartiopsis gen. nov. and its context in Anacardiaceae classification. Systematic Botany 31: 337-348. DOI: https://doi.org/10.1600/036364406777585757

Mota L. (2014). Evolution of haploid chromosome numbers in the sunflower family. Are genomic duplications associated to ancient climate changes? M.Sc. thesis. Faculty of Sciences and Technology, University of Coimbra, Portugal.

Mukherjee S.K. (1950). Cytological investigation of the mango (Mangifera indica L.) and the allied Indian species. Proceedings of National Institute of Science of India 16: 287-303.

Mukherjee S.K. (1957). Cytology of some Malayan species of Mangifera. Cytologia 22: 239-241.

DOI: https://doi.org/10.1508/cytologia.22.239

Muller J. (1984). Significance of fossil pollen for angiosperm history. Annals of the Missouri Botanical Garden 71: 419-443. DOI: https://doi.org/10.2307/2399033

Oginuma K., Damas K. \& Tobe H. (1999). A cytology of some plants from Papua New Guinea: additional notes. Acta Phytotaxonomica et Geobotanica 50: 43-50.

Oginuma K., Kato A., Tobe H., Mathenge S.G. \& Juma F.D. (1993). Chromosomes of some woody plants in Kenya. Acta Phytotaxonomica et Geobotanica 44: 53-58.

Osborn T.C. et al. (11 authors) (2003). Understanding mechanisms of novel gene expression in polyploids. Trends in Genetics 19: 141-147. DOI: https://doi.org/10.1016/S0168-9525(03)00015-5

Paiva J. \& Leitao M.T. (1989). Números cromossómicos para alguns taxa da Africa tropical II. Boletim da Sociedade Broteriana 2:117-130.

Parfitt B.D., Pinkava D.J., Rickel D., Fillipi D., Eggers B. \& Keil D.J. (1990). Documented chromosome numbers 1990: 1. Miscellaneous North American vascular plants. SIDA, Contributions to Botany 14: 305-308.

Parfitt D.E. \& Badenes M.L. (1997). Phylogeny of the genus Pistacia as determined from analysis of the chloroplast genome. Proceedings of the National Academy of Sciences 94:7987-7992.

DOI: https://doi.org/10.1073/pnas.94.15.7987

Pell S.K. (2004). Molecular systematics of the cashew family (Anacardiaceae). PhD thesis. Louisiana State University, USA.

Pell S.K., Mitchell J.D., Miller A.J. \& Lobova T.A. (2010). Anacardiaceae. In: The Families and Genera of Vascular Plants, Flowering Plants Eudicots: Sapindales, Cucurbitales, Myrtaceae, volume 5 (ed. K. Kubitzki), pp. 7-50. Springer, Berlin, Germany.

Pierozzi N.I. \& Rossetto C.J. (2006). Chromosome characterization of two varieties of Mangifera indica L. Revista Brasileira de Fruticultura 33: 546-551. DOI: https://doi.org/10.1590/S0100-29452011000500074

Raven P.H. (1975). The bases of angiosperm phylogeny: cytology. Annals of the Missouri Botanical Garden 62(3): 724-764.

DOI: https://doi.org/10.2307/2395272

Ronquist F. \& Huelsenbeck J.P. (2003). MRBAYES 3: Bayesian phylogenetic inference under mixed models. Bioinformatics 19:1572-1574.

DOI: https://doi.org/10.1093/bioinformatics/btg180

Russell A., Samuel R., Rupp B., Barfuss M.H.J., Šafran M., Besendorfer V. \& Chase M.W. (2010). Phylogenetics and cytology of a pantropical orchid genus Polystachya 
(Polystachyinae, Vandeae, Orchidaceae): Evidence from plastid DNA sequence data. Taxon 59: 389-404.

DOI: https://doi.org/10.1002/tax.592005

Samuel R., Kathriarachchi H., Hoffmann P., Barfuss M.H., Wurdack K.J., Davis C.C. \& Chase M.W. (2005). Molecular phylogenetics of Phyllanthaceae: evidence from plastid matK and nuclear PHYC sequences. American Journal of Botany 92: 132-141.

DOI: https://doi.org/10.3732/ajb.92.1.132

Schneeweiss G.M., Palomeque T., Colwell A.E. \& WeissSchneeweiss H. (2004). Chromosome numbers and karyotype evolution in holoparasitic Orobanche (Orobanchaceae) and related genera. American Journal of Botany 91: 439-448.

DOI: https://doi.org/10.3732/ajb.91.3.439

Singhal V.K. \& Gill B.S. (1990). Chromosomal studies in some members of Anacardiaceae. Journal of Cytology and Genetics 25: 36-42.

Soltis D.E., Albert V.A., Leebens-Mack J., Bell C.D., Paterson A.H., Zheng C., Sankoff D., Wall P.K. \& Soltis P.S. (2009). Polyploidy and angiosperm diversification. American Journal of Botany 96: 336-348. DOI: https://doi.org/10.3732/ajb.0800079

Souza H.A.V., Muller L.A.C., Brandão R.L. \& Lovato M.B. (2012). Isolation of high quality and polysaccharide-free DNA from leaves of Dimorphandra mollis (Leguminosae), a tree from the Brazilian cerrado. Genetics and Molecular Research 11: 756-764.

DOI: https://doi.org/10.4238/2012.March.22.6

Stamatakis A. (2014). RAxML ver. 8: a tool for phylogenetic analysis and post-analysis of large phylogenies. Bioinformatics 30: 1312-1313.

DOI: https://doi.org/10.1093/bioinformatics/btu033

Swofford D. (2003). 'PAUP*: phylogenetic analysis using parsimony, ver.4, Smithsonian Institution Press, Washington, D.C, USA.

Takhtajan A. (1987). Systema Magnoliophytorum. Nauka, Leningrad, Russia.

Takhtajan A. (1997). Diversity and classification of flowering plants. Columbia University Press, New York, USA.

Terrazas T. (1994). Wood anatomy of the Anacardiaceae: ecological and phylogenetic interpretation. $P h D$ dissertation, University of North Carolina, Chapel Hill, USA.

Vinicius da Luz L., da Silva A.C.F., Laughinghouse IV H.D., Tedesco B.S. \& Coelho A.P.D. (2015). Cytogenetic characterization of Schinus terebinthifolius Raddi (Anacardiaceae) accessions from Rio Grande do Sul State, Brazil. Caryologia 68: 132-137.

DOI: https://doi.org/10.1080/00087114.2015.1032573

Vladimirov V. \& Dimitrova D. (2007). Chromosome numbers of selected species from the Bulgarian flora. Phytologia Balcanica 13: 379.

Wannan B.S. \& Quinn C. (1990). Pericarp structure and generic affinities in the Anacardiaceae. Botanical Journal of the Linnean Society 102: 225-252. DOI: https://doi.org/10.1111/j.1095-8339.1990.tb01878.x

Wannan B.S. \& Quinn C. (1991). Floral structure and evolution in the Anacardiaceae. Botanical Journal of the Linnean Society 107: 349-85.

DOI: https://doi.org/10.1111/j.1095-8339.1991.tb00228.x

Weiss-Schneeweiss H., Stuessy T.F. \& Villaseñor J.L. (2009). Chromosome numbers, karyotypes, and evolution in Melampodium (Asteraceae). International Journal of Plant Sciences 170: 1168-1182.

DOI: https://doi.org/10.1086/605876

Wendel J.F. (2000). Genome evolution in polyploids. Plant Molecular Biology 42: 225-249. DOI: https://doi.org/10.1007/978-94-011-4221-2 12

White T.J., Bruns T., Lee S. \& Taylor J.W. (1990). Amplification and direct sequencing of fungal ribosomal RNA genes for phylogenetics. In: PCR Protocols: A Guide to Methods and Applications (eds. M.A. Innis, D.H. Gelfand, J.J. Sninsky \& T.J. White), pp. 315-322. Academic Press, Inc. New York, USA.

DOI: https://doi.org/10.1016/B978-0-12-372180-8.50042-1

Yi T., Miller A.J. \& Wen J. (2007). Phylogeny of Rhus (Anacardiaceae) based on sequences of nuclear Nia-i3 intron and chloroplast trnC-trnD. Systematic Botany 32: 379-391. DOI: https://doi.org/10.1600/036364407781179635

Zotz G. (2013). The systematic distribution of vascular epiphytes-a critical update. Botanical Journal of the Linnean Society 171: 453-481.

DOI: https://doi.org/10.1111/boj.12010 